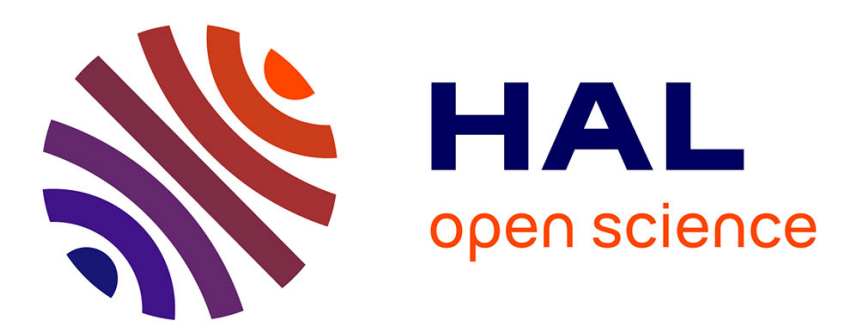

\title{
Topology Optimisation of a 3D Electromagnetic Device using the SIMP Density-Based Method
}

Bilquis Mohamodhosen, Frédéric Gillon, Abdelmounaim Tounzi, Loïc Chevallier, Julien Korecki

\section{To cite this version:}

Bilquis Mohamodhosen, Frédéric Gillon, Abdelmounaim Tounzi, Loïc Chevallier, Julien Korecki. Topology Optimisation of a 3D Electromagnetic Device using the SIMP Density-Based Method. 2016 IEEE Conference on Electromagnetic Field Computation (CEFC), Nov 2016, Miami, United States. 10.1109/CEFC.2016.7816001 . hal-01756843

\section{HAL Id: hal-01756843 https://hal.science/hal-01756843}

Submitted on 7 Dec 2018

HAL is a multi-disciplinary open access archive for the deposit and dissemination of scientific research documents, whether they are published or not. The documents may come from teaching and research institutions in France or abroad, or from public or private research centers.
L'archive ouverte pluridisciplinaire HAL, est destinée au dépôt et à la diffusion de documents scientifiques de niveau recherche, publiés ou non, émanant des établissements d'enseignement et de recherche français ou étrangers, des laboratoires publics ou privés. 


\title{
Topology Optimisation of a 3D Electromagnetic Device using the SIMP Density-Based Method
}

\author{
Bilquis Mohamodhosen, Frédéric Gillon, Abdelmounaïm Tounzi and Loïc Chevallier \\ Univ. Lille, Centrale Lille, Arts et Metiers ParisTech, HEI, EA 2697 - L2EP - Laboratoire \\ d'Electrotechnique et d'Electronique de Puissance, F-59000 Lille, France \\ bilquis.mohamodhosen@ec-lille.fr
}

\begin{abstract}
The presented paper proposes a topology optimisation methodology based on the density-based method SIMP, and applied to a numerical example to validate the former. The approach and methodology are detailed, and the results for a 3D basic electromagnetic example are presented. The non-linear $\mathbf{B}(\mathbf{H})$ curve is also taken into account.

Index Terms - gradient-based algorithm, relaxation of variables, SIMP density method, weighted objective sum
\end{abstract}

\section{INTRODUCTION}

Topology Optimisation (TO) arouses growing interest in the electromagnetic community as it proposes a new way of tackling the general engineering problem: finding the most optimal design to maximize performance and minimize cost. TO offers the freewill of finding the best design without any layout a priori, given appropriate formulation of optimization objectives and constraints to be consistent with the problem.

Various authors have investigated the topic, presenting different methods to deal with it, but our main interest in this paper will be focused on the SIMP (density-based) method [1] due to its ease of application and reproducibility. However, this method presents some weaknesses related to the unavoidable relaxation of variables (discrete to continuous) while using a gradient-based algorithm, giving rise to undesired intermediate variables. This paper presents a methodology devised to solve this problem, and a numerical example using Finite Element (FE) Analysis for validation.

\section{PROBLEM FORMULATION}

In electromagnetic applications, it is usually desired to maximise an objective function such as force or energy, while using the least Material Quantity $(M Q)$ in the design. The structure is modelled by FE, and calculations are done by a laboratory developed calculation code (code_Carmel) coupled with gradient-based fmincon $S Q P$ algorithm via a laboratory developed optimisation platform (Sophemis). This has the advantage of outputting an electromagnetically coherent design at each iteration, and hence increasing the probability of obtaining the best 'feasible' design. In this paper, it is desired to produce the best structure made of iron and air as materials, represented by $n$ number of variables $\rho$ varying from 0 to 1 , where 0 is air and 1 is iron. To prevent existence of undefined intermediate materials (e.g. at 0.5) in the final design, we propose to add a Feasibility Factor $(F F)$ to force the values to 0 and 1 . The optimisation problem is defined as in equation 1 .

$$
\left\{\begin{array}{c}
f(\rho): \min (-(1-\alpha) \cdot g(\rho)+\alpha \cdot|F F(\rho)|) \\
\text { Such that } M Q \leq \beta \\
\text { Where } F F=\sum_{i=1}^{n} \rho_{i}\left(\rho_{i}-1\right)=0
\end{array}\right.
$$

The main objective $g(\rho)$ is maximised, and can also be written as the minimisation of the negative value of $g(\rho)$. The coefficient $\alpha$ is used to weigh the prominence of $F F$ w.r.t the main objective in the problem. If $\alpha$ is less than $0.5, F F$ will have a reduced, yet substantial importance in problem solving as compared to $g(\rho) . M Q$ is constrained to $\beta$, where $\beta$ is the maximum amount of iron allowed in the design.

\section{NUMERICAL EXAMPLE}

A basic 3D numerical example (fig. 1) is used to validate the methodology. The initial domain used is a cube meshed into 4096 hexahedral elements (fig. 1a) where a Magnetic Potential Difference is applied to the nodes highlighted with white dots. The number of variables used is 64 , with therefore 64 hexahedra per variable (green outlined cube). The aim is to find the most optimum design that maximises the energy (hence minimises negative value of energy), with the $M Q$ constrained to $75 \%$. The weightage $\alpha$ is set to 0.25 . The final design is given in fig. $1 \mathrm{~b}$, where the white zones represent air and black represent iron, and the Magnetic Flux Density $B$ given in fig. 1c.

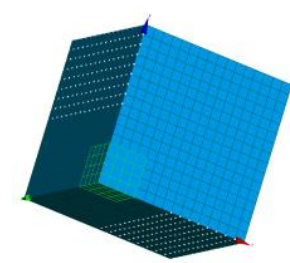

Fig. 1. (a) FE Model,

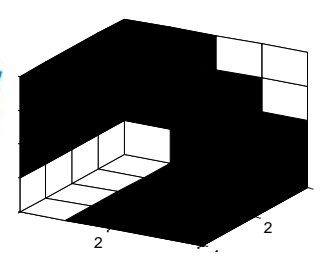

(b) Final design, (c) Magnetic Flux Density, $B(\mathrm{~T})$
Optimisations are done using a linear, as well as non-linear $\mathrm{B}(\mathrm{H})$ behaviour assumption with same initial parameters. Both yield the same topology, with a calculation time of 5 mins and $\max B$ of $3.5 \mathrm{~T}$ for linear case, and 20 mins with $\max B$ of $1.3 \mathrm{~T}$ for non-linear case. In the extended paper version, more details will be given on the application of the methodology to optimise the topology of an electromagnet as in [2].

\section{REFERENCES}

[1] G. I. N. Rozvany, M. Zhou, et T. Birker, "Generalized shape optimization without homogenization”, Struct. Optim., vol. 4, no 3-4, p. 250-252, sept. 1992.

[2] Y. Okamoto, Y. Tominaga, S. Wakao, et S. Sato, "Improvements in Material-Density-Based Topology Optimization for 3-D Magnetic Circuit Design by FEM and Sequential Linear Programming Method", IEEE Trans. Magn., vol. 50, nº 2, p. 689-692, feb. 2014. 